\title{
Corela
}

Cognition, représentation, langage

HS-35 | 2022

Anaphore et pronoms en anglais : convergences, différences et complémentarité de quelques approches linguistiques

\section{CORPUS Anaphore}

Tony Robbins: Why we do what we do

\section{(2) OpenEdition}

12 Journals

\section{Édition électronique}

URL : https://journals.openedition.org/corela/14440

DOI : 10.4000/corela. 14440

ISSN : 1638-573X

\section{Éditeur}

Cercle linguistique du Centre et de l'Ouest - CerLICO

Référence électronique

«CORPUS Anaphore », Corela [En ligne], HS-35 | 2022, mis en ligne le 11 janvier 2022, consulté le 26 janvier 2022. URL : http://journals.openedition.org/corela/14440 ; DOI : https://doi.org/10.4000/ corela. 14440

Ce document a été généré automatiquement le 26 janvier 2022.

\section{(c) (i) (2)(2)}

Corela - cognition, représentation, langage est mis à disposition selon les termes de la licence Creative Commons Attribution - Pas d'Utilisation Commerciale - Partage dans les Mêmes Conditions 4.0 International. 


\section{CORPUS Anaphore}

Tony Robbins: Why we do what we do

https://www.ted.com/talks/tony_robbins_asks_why_we_do_what_we_do?

language $=$ enFilmed February 2006 at TED2006 